Naskah diserahkan: 30-08-2021 Diterima: 06-09-2021

\title{
Students Vocabulary Mastery toward Crossword Puzzle Games
}

\author{
Rahmat Nasrullah ${ }^{1 *}$, Nur Rizky Alfiany ${ }^{2}$, Muhammad Ainul Hamdan ${ }^{3}$ \\ Pendidikan Bahasa Inggris, Universitas Muhammadiyah Kendari ${ }^{1,2,3}$ \\ Email Korespondensi: rahmat.nasrullah@umkendari.ac.id
}

\begin{abstract}
This research investigated the improvement of students' participation and vocabulary achievement by using crossword puzzles in the classroom. The research design was Classroom Action Research (CAR) conducted in two cycles. The research subjects were the seventh-grade students and the research area was at a private Islamic Junior High School in Kendari. The data were collected by using observation and vocabulary achievement tests. The collected data were analyzed statistically by using a percentage formula. The students' activity improved from $78,66 \%$ in cycle 1 to $97,66 \%$ in cycle 2 . Meanwhile, the students' vocabulary mastery improved from $54 \%$ in cycle 1 to $90 \%$ in cycle 2 . In conclusion, using crossword puzzles improved the students' vocabulary achievement and students' participation in the teaching and learning English.
\end{abstract}

Keywords: Games, CAR, mastery

ABSTRAK: Penelitian ini menginvestigasi peningkatan partisipasi siswa dan prestasi kosakata dengan menggunakan teka-teki silang di kelas. Desain penelitian menggunakan prosedur Penelitian Tindakan Kelas (PTK) yang dilakukan dalam dua siklus. Subjek penelitian adalah siswa kelas tujuh. Sedangkan tempat penelitian dilakukan di Sekolah Menengah Pertama (SMP) Islam di Kendari. Data dikumpulkan menggunakan pengamatan dan tes prestasi kosakata. Data yang dikumpulkan dianalisis secara statistik dengan menggunakan formula persentase. Hasil penelitian menunjukkan bahwa kegiatan siswa meningkat dari 78,66\% (siklus) ke 97,66\% (siklus 2). Sementara itu, penguasaan kosakata siswa meningkat dari 54\% pada siklus 1 hingga 90\% pada siklus 2. Dengan demikian, peneliti menyimpulkan bahwa dengan menggunakan teka-teki silang, prestasi kosakata dan partisipasi siswa dalam mengajar dan belajar bahasa Inggris dapat ditingkatkan.

Kata kunci: Penguasaan, Permainan, dan PTK.

\section{BACKGROUND}

Vocabulary is one of the imperative aspects to support Englih language skills. As stated by Richards and Renandya (2002), vocabulary is a core component of language proficiency and provides much of the basis of how well learners speak, read, listen and write. For instance, in listening skills, to be able to understand speech and utterance, people should know the meaning of words and sentences being said. Hence, they know the intention of the utterance and can react either 
through action or answer it using spoken utterance, which here, they have to use words to do that. To be able to understand what people are reading, they should be able to understand the meaning that is being conveyed through the written words. Vocabulary has been an imperative component in language development. Vocabulary is as important as grammar as the building blocks of language (Ghadessy, 1998; cited in Sripramong, 2004). Students are required to possess more vocabulary to support their language production.

Based on the preliminary study at MTs Al-Muhajjirin Darussalam, the researcher noticed that students are facing challenges in enriching English vocabulary mastery. The researcher asked students to write down the vocabulary as far as they know and the result was most of the students have limited vocabulary. Of 22 students, few students could write 50 words. The other problem could be seen from low scores in vocabulary and students got difficulties in four aspects of vocabulary, such as spelling, meaning, and pronunciation. Thornbury (2002) states that lack of vocabulary knowledge impedes language comprehension and production. Many students are still facing big problems in memorizing vocabulary, especially for the students of junior high school. It means that the students should be made to feel relaxed and enjoyable during the learning process.

In relevant to the before mentioned problems, games can be used to make students feel enjoyable, active (Sumarni \& Amin, 2021), and effective in developing skills (Pahendra et al., 2021). A game if it contains activities of thought, heart, feeling, intention, and sports and contains positive values can be input to the curriculum (Nasir, Rahmawati, \& Adam, 2019).

Crossword puzzle games seem to provide enjoyable activities in the classroom and help students enhance vocabulary mastery. Case (1994) states that puzzle games are useful for language learners because they can present excitement, satisfaction, and improvement in the classroom. The games can encourage to maximize dictionary usage and can be used for any different types of classroom activities and phases. From the explanation above, the researcher was interested in using crossword puzzle games to improve the quality of the learning process and help students to learn English in interesting ways. Besides, students are expected to gain English vocabulary mastery to support them in producing language.

This study aimed to examine the use of crossword puzzle games in English class at junior high school level. It is expected to bring more insights and views related to the use of games in language class and also provide meaningful learning for students at the same time they are able to improve their English skills.

\section{RESEARCH METHODOLOGY}

In this study the researcher used classroom action research. The classroom action research procedure used in this study Kart Lewin's design. It consisted least two cycles in which each cycle consists four phases: Planning, acting, observing and reflecting. McMilan (1992: 2) states that a classroom 
action research is a type of applied research in which its purpose is to solve a specific classroom problem. So, this classroom action research is a research which is intended to solve practical problem in teaching learning process. This classroom action research was intended to overcome the students' problem on vocabulary and the improvement of their vocabulary achievement. Based on this study, the researcher focused on learning process by using crossword puzzle at seventh grade students of MTs Al-Muhajirin Darussalam.

There are two kinds to collect the data. They were vocabulary test and observation sheet. Vocabulary test in this research would be given to student in order to measuring students' achievement by using crossword puzzle after the action research is done. The purpose of vocabulary test was to measure how successful individual students the goal of teaching and learning process. The observation would be conducted eight times during meeting in order to see the process of teaching using crossword puzzle during the observation, the researcher would use observation sheet, and will helped by crossword puzzle. Procedure of conducting observation was the researcher would involve directly in the classroom.

\section{RESULT AND DISCUSSION}

\section{Results}

The implementation of the action in first cycle was done in four meetings. They were carried out based on Lesson Plan 1, 2, and 3 which were constructed by the researcherand consulted to the consultant and the English teacher. The first meeting in cycle 1 was done on May 11, 2018, the second meeting was carried out on on May 14, 2018, and the third meeting was conducted on May 18, 2018. The vocabulary test was conducted in fourth meeting on May 21, 2018. The researcher explained the finding of vocabulary test in term of students' vocabulary achievement in the first cycle as exposed in the following table:

Table 1 Students score, Mean, and Classical Competence in Cycle 1

\begin{tabular}{|c|c|}
\hline Total & 1.492 \\
\hline Maximal Score & 88 \\
\hline Minimal Score & 44 \\
\hline Mean & 67 \\
\hline Percentage of KKM's Achievement (75\%) & $54 \%$ \\
\hline
\end{tabular}

The result of the students" score in cycle 1 was taken from the value which was marked by the researcher. The result showed that in first cycle, there were 12 students who reached the target and there were 10 students did not. The total score of 22 students was 1,492. The highest score was 88 and the lowest score was 44 . Mean score was 67 . The classical completeness according to school standard was $75 \%$. It means that the KKM was not reached yet. In other words, $25 \%$ needed to complete the score of classical completeness. 
The action was continued in the cycle two because in first cycle did not achieve the target in this study. The implementation in first meeting was conducted on May 25, 2018, the second meeting on May 28, 2018, and the third meeting was carried out on June 1, 2018 while the vocabulary test was conducted in June 4, 2018. The findings of vocabulary test in terms of student's vocabulary in the second cycle as exposed in the table:

Table 2

Students Score, Mean, and Classical Completeness in Cycle 2

\begin{tabular}{|c|c|}
\hline Total & 1.868 \\
\hline Maximal Score & 96 \\
\hline Minimal Score & 60 \\
\hline Mean & 85 \\
\hline Percentage of KKM's Achievement (75\%) & $90 \%$ \\
\hline
\end{tabular}

There were 20 students who reached the target and only 2 students did not. The total score of 22 students was 1,868. It means that the researcher was success in cycle 2 . The percentage of classical completeness was $90 \%$. The highest score was 96 and the lowest score was 60 . Mean score was 85 .

\section{The Attainment of the Teacher and Students on the Learning Process}

In this study the researcher used observation sheet to measure the progress of learning. Based on the observation sheet for the teacher and the students was a significant advance in the learning process during the applying of crossword puzzle. The result of the observation can be seen below this table below:

Table 3 The result of observation of teacher and students

\begin{tabular}{|c|c|c|}
\hline \multirow{2}{*}{ Meeting / Cycle } & \multicolumn{2}{|c|}{ Percentage (\%) } \\
\cline { 2 - 3 } & Students & Teacher \\
\hline $1 / 1$ & $69 \%$ & $70 \%$ \\
\hline $2 / 1$ & $76 \%$ & $88 \%$ \\
\hline $3 / 1$ & $92 \%$ & $94 \%$ \\
\hline $1 / 2$ & $92 \%$ & $88 \%$ \\
\hline $2 / 2$ & $100 \%$ & $94 \%$ \\
\hline $3 / 2$ & $100 \%$ & $100 \%$ \\
\hline Total of Percentage & $\mathbf{5 2 9 \%}$ & $\mathbf{5 3 4 \%}$ \\
\hline
\end{tabular}

Based on the data above, the first meeting of the students' activities of the first cycle $69 \%$ that was lower than others, the second meeting of the first cycle $76 \%$, and at the third meeting was increase $92 \%$. In the second cycle at the first meeting $92 \%$, at the second meeting $100 \%$. and at the last meeting same $100 \%$. It means that, if we should be determining the learning process during 2 cycle of teaching in the class, thestudents reached $529 \%$.

Percentage of the teacher from the first meeting until third meeting of first cycle were increase, where the first meeting of performance was $70 \%$, second meeting $88 \%$, and the last meeting $94 \%$. In the second cycle of the first 
meeting $88 \%$, the second meeting $94 \%$ and the last meeting was complete $100 \%$.

Clearly, it can be seen the improvement between teacher and students' progress in the chart below during teaching and learning process in each meeting. Moreover, the following chart described the result of the students' observation sheet in each cycle.

\section{Discussion}

The first improvement was spelling aspect from crossword puzzle. Spelling ability in language learning is the basic need to reach a good achievement of the target language. According to Hadfield (2004) Crossword puzzle is effective teaching tool of terminology, definitions, spelling and pairing key concepts with related names, resulting in greater retention and memorization of facts. Crossword puzzle is a game that has some squares, if the students fill the squares of course they knew the spelling of the word. Meanwhile, crossword puzzle was also applied each of meeting. The teaching and learning activity by using crossword puzzles showed a positive effect on the students' achievement. The students' spelling of simple words during the teachinglearning activities by using crossword puzzles was good.

The second improvement by applying crossword puzzle was stimulating students to be relax because in learning of crossword puzzle, the students were not suppressed, they only asked to fill the square in the blank of crossword puzzle by cooperating with group mate. According to Karim and Hasbullah (1986) stated that crossword puzzle can make students relax and free in teaching learning process.

The last improvement was vocabulary aspect. In first cycle, students got $54 \%$ classical competence and the second cycle it increased $90 \%$ classical competence. Jones (2013: 3) stated that the use of crossword puzzles in the classroom will help the students' sharpen their mental skill because by reading the clues and looking at the corresponding slots, the students will already know how many letters the answer has. Moreover, by solving a crossword puzzle, it will help students improve their vocabulary. It was proved with them result of their participation during the teaching learning process in every meeting. Crossword puzzle engaged the students with the material because by solving the clues given and filling in the squares, the students were motivated in learning vocabulary.

\section{CONCLUSION}

The teaching learning process by using crossword puzzle gave the positive effect in improving the student's vocabulary and the student's motivation in learning vocabulary. This is shown by the students' enthusiasm in doing crossword puzzle and most of the students more understand what the teacher said in cycle II than in cycle I. Moreover, the student's achievement of vocabulary has improved by using crossword puzzle in teaching learning process. 


\section{REFERENCES}

Case. (2012). Improving English Vocabulary Mastery by Using Crossword Puzzle. Dini Restu Profita , 4.

Ghadessy. (1998). Using Games on P.6 Students' Vocabulary Learning. Thailand.

Hadfield. (2004). Crossword Puzzle as an Effective Way to Teach English Vocabulary. Combridge: Combridge University Press.

Indrasari. (2015). Improving the VIII C students' vocabulary achievement by Using Crossworzd Puzzle at SMP Negeri 2 Lumajang. Thesis. FKIP, Jember University.

Jones, K (2013). Teaching with Vocabulary. [on line]. http://Vocabulary.co.il/learning_voabulary/teaching-with-crosswordpuzzle.

Karim, M. and Hasbullah, F. A. (1986). Language Teaching Media. Jakarta: Universitas Terbuka.

McMilan, J. H. (1992). Educational Research: Fundamental for Costumers. NewYork: Harper Collin Publisher.

Nasir, N., Rahmawati, R., \& Adam, A. (2019). Identifikasi Nilai Pedagogis Tarian Lulo untuk Memperkuat Rasa Persatuan pada Anak Usia Dini. Jurnal Obsesi: Jurnal Pendidikan Anak Usia Dini, 4(1), 371. https://doi.org/10.31004/obsesi.v4i1.336

Pahendra, Selman, H., Rohmiati, Said, H., Sasnita, U., Nasir, \& Indah, T. (2021). Sirkuit Bola Keranjang: Permainan untuk Meningkatkan Kemampuan Motorik Kasar Anak Usia Dini. Obsesi, 5(2), 2025-2036. https://doi.org/10.31004/obsesi.v5i2.1077

Richards, Jack C. and Willy A. Renandya. (2002). Methodology in Language Teaching: An Anthology of Current Practice. New York. CambridgeUniversity Press.

Sumarni, S., \& Amin, M. (2021). Puzzle dan Problem Solving: Media dan Pendekatan untuk Meningkatkan Partisipasi dan Hasil Belajar Siswa. Journal of Education and Teaching (JET), 2(1), 36-43. https://doi.org/10.51454/jet.v2i1.67

Thornbury, S., (2002). How to teach vocabulary, UK: Longman.

Trianto. (2016). Improving Class VIII D Students' Participation and Vocabulary Achievement by Using Crossword Puzzles At SMPN 1 Tanggul. EFL Education Journal. Vol. 3, No. 7. 